Article

\title{
Economic Impact of Tariff Rate Quotas and Underfilling: The Case of Canned Fruit Exports from South Africa to the EU
}

\author{
Chiedza L. Muchopa (D) \\ Department of Agricultural Economics, University of Limpopo, Polokwane 0727, South Africa; \\ cmuchopa@vodamail.co.za
}

Citation: Muchopa, Chiedza L.. 2021. Economic Impact of Tariff Rate Quotas and Underfilling: The Case of Canned Fruit Exports from South Africa to the EU. Economies 9: 155. https://doi.org/10.3390/economies 9040155

Academic Editors: Michał Roman and Monica Roman

Received: 26 June 2021

Accepted: 10 September 2021

Published: 18 October 2021

Publisher's Note: MDPI stays neutral with regard to jurisdictional claims in published maps and institutional affiliations.

\begin{abstract}
Export trade provided for under tariff rate quotas (TRQs) is an important contributor to improving South Africa's export access to European markets. The performance of exporteradministered TRQs has not received much research attention in the context of the below par market access utilisation of a given opportunity. The present study analysed how the country performed in terms of utilising its TRQ for canned pears, apricots, and peaches provided by the European Union (EU) for the period 2010 to 2019. The permit allocation system for TRQs in South Africa is described for further understanding of aspects of the TRQ system likely to affect quota fill. Performance was assessed in terms of yearly quota utilisation rates as well as welfare measured in equivalent variation calculated in a computable general equilibrium (CGE) trade model. The analysis found that the canned fruit TRQ exhibited a fill rate average of $61 \%$ for the past 10 years (2010-2019) and 49\% for the period 2015-2019, thus falling far short of the goal of achieving full market access availed by the EU within the protocols of liberalised trade. The welfare effects of trade liberalisation confirmed the underutilisation of the TRQ indicated by a welfare loss, considering the difference in gains of an underutilised quota (USD 2497) and a fully utilised quota (USD 2530). The study highlights the importance of full utilisation of preferences.
\end{abstract}

Keywords: agriculture; fruit products; tariff rate quota; welfare; trade policy; TRQ administration

\section{Introduction}

Open and fully liberalised trade is crucial for the South African fruit industry given its reliance on exports. The National Agricultural Marketing Council (NAMC 2017) noted that the fruit sector contributed the largest value share in the country's agricultural exports and that $90 \%$ of fruit production was exported internationally. Only $29 \%$ of the total fruit production in South Africa goes to processing, as noted in van Lin et al. (2018). Approximately $80 \%$ of canned fruit is exported annually by South Africa and the European Union (EU) market is reported among South Africa's major export destinations (Bertelsmann-Scott and Markowitz 2018; Research and Markets 2021). Evidently, scope exists for value addition in the sub-sector of canned fruits targeted for exports. Though the EU is among the major export destinations, processed fruit products face stiff entry barriers and this has been identified in studies such as Bertelsmann-Scott and Markowitz (2018), noting how African exporters are impacted by developed countries' trade policies.

South Africa's share in the exports of "sensitive"1 agricultural products to the EU ${ }^{2}$ is governed by the use of tariff rate quotas (TRQs) by the EU, which seeks to protect its agricultural market. TRQs are defined in Skully (2001) as "a two-tiered tariff system" in which in-quota imports face a lower tariff than out-of-quota imports. TRQs are considered in trade theory to be less restrictive than pure quotas, thus improving welfare to the extent of the quota fill. However, full TRQ liberalisation (zero in-quota tariff) has the potential to further liberalise trade and improve market access. The TRQ that consists of a combination of canned pears, apricots, and peaches (hereafter referred to as canned fruits ${ }^{3}$ TRQ) is a major (70-80\%) export value contributor (see Appendix A Table A1) among six EU fruit 
products TRQs implemented and administered in South Africa through a permit allocation system managed by the then Department of Agriculture, Forestry and Fisheries (DAFF) ${ }^{4}$ as part of the obligations and provisions on TRQs for fruit products contained in the EUSouth Africa free trade agreement (TDCA 1999), the Trade Development and Cooperation Agreement (TDCA). The TDCA paved the way for South Africa to export fruit products on the EU's sensitive list and the provisions of the agreement are such that the TRQ is administered by the exporter. There are no studies describing the TRQ administration of a unilateral TRQ offered by the EU to a third country (a country other than an EU member state $)^{5}$ and the present study provides context by describing such a TRQ administration, thus contributing to a better understanding of the institutional context within which the trade policy instrument operates.

Though the canned fruits TRQ is the major earner amongst the fruit products TRQs, its performance (in terms of fill rates, the share in tariff line coverage of fruit TRQ exports to the EU, and welfare effects) needs to be more clearly understood. To this end, after describing the TRQ administration system of the exporting country, the paper assesses how the canned fruits TRQ performed focusing on the canned pears, apricots, and peaches tariff lines that correspond to the Harmonised System (HS) ${ }^{6}$ of commodity description codes HS 2008.40/50/70. Tariff line coverage and fill rates of the TRQ were analysed to determine the extent to which the yearly TRQs were utilised and finally, a case study of the canned fruits TRQ was used for the empirical analysis of the welfare effects of TRQ liberalisation. Trade theory provides a framework to analyse trade policy instruments such as the TRQ implementation for which static effects can be determined in three different cases, namely, where exports are equal to the quota granted, exports are less than the quota granted, or exports exceed the quota granted (Abbott and Paarlberg 1998; Skully 2001). The case of the canned fruits TRQ in this study is the situation where exports are less than the quota granted, meaning that the effective instrument is the in-quota tariff. Hence, the goal of this study is to quantify the economic impact of the TRQ on welfare after considering a policy change where the in-quota tariff is fully liberalised. The hypothesis is therefore that the in-quota tariff impacts economic welfare. This paper uses the widely accepted static GTAP model to quantify economic welfare measured in equivalent variation. Additionally, the present study does not quantify the extent of impact of the TRQ administration system on TRQ fill but analyses the welfare impacts measured in equivalent variation (EV) in a comparison of scenarios of the filled and under-filled canned fruits TRQ.

The paper is organised as follows. The introduction section is followed by a literature review. The methodology is presented in Section 3, followed by findings and discussion in Section 4 and the conclusion in Section 5.

\section{Literature Review}

The theoretical literature on trade policy liberalisation focusing on the TRQ instrument, a synopsis of the global policy goals of TRQs, and the associated TRQ permitting systems as well as a summary of previous studies on TRQ liberalisation, are presented in this section. The implementation of the TRQ policy finds favour with exporters and importers for different reasons, especially in the context of sensitive agricultural products. TRQs arose under the Uruguay Round trade negotiations (1986-1994) on agriculture as a means to improve market access for imports (WTO Market Access Group 1993; Skully 2001; Pouliot and Larue 2012). Based on the same principles upon which TRQs were founded, the canned fruits TRQ discussed in this study was negotiated to achieve the main stated objective of achieving improved market access spelt out under the obligations of the TDCA. The challenge of frequent under-fill of quotas, however, as confirmed recently by Beckman et al. (2017), has dominated the agricultural market access debate. The World Trade Organisation reports (WTO Committee on Agriculture 2018, 2020) of the Committee on Agriculture note the existence of a total of 1128 schedules of TRQs and an annual average fill rate of $54 \%$ over all TRQs in 2016 and 46\% in 2019. Skully (1999), at the onset, elaborated that the administration of quotas and quota fill is a principle of the General Agreement on Tariffs 
and Trade (GATT) that declares that quota fill regulations need not act as trade barriers. Though the quota fill principle focuses on importer administration of TRQs, that same principle directs no particular attention to exporter administered TRQ rules, which are ideally the same rules that possibly inhibit quota fill as highlighted in some of the previous studies reviewed in Section 2.2.

\subsection{Theoretical Framework}

The assessment of possible welfare changes due to trade liberalisation has a theoretical basis in the analysis of policy changes credited to Harberger (1971) for identifying four sources of economic welfare induced by a policy change. The four sources identified were new technology, improved trading terms, new resources, and deadweight loss. The application of this theory was established by Huff and Hertel (1996) through implementing the conceptualisation by Harberger (1971) in the GTAP CGE model to decompose the equivalent variation welfare measure into the widely accepted sources indicated as changes in terms of trade, allocative efficiency, endowment effects, and technology effects that can be quantified following a policy shock to the model. The approach provides a mechanism to quantify economic welfare impacts of liberalising a tier of the TRQ, namely the in-quota tariff in the present study of the canned fruits TRQ. The tariff liberalisation is a policy change and the standard method in the GTAP model concerning sector aggregation is not practical to analyse the TRQ, hence the modification of the sector as stated in the methodology section was implemented for this study to accommodate the analysis of the canned fruits TRQ.

Skully (2001) provided a framework to understand the liberalisation of TRQs, identifying the liberalisation actions among which the reduction of in-quota tariffs and expansion of the quota was prescribed for persistently under filled TRQs. Furthermore, Bagwell and Staiger (2016) provided the basis to understand the terms of trade effects and explained that, once the domestic price and the terms of trade are determined, production as well as consumption and tariff revenue are all inferred. The decomposition of welfare changes in a GTAP model therefore enabled the investigation of welfare changes emanating from TRQ policy liberalisation in this present study. The pioneering study of Skully (2001) also acknowledges that the impact of different TRQ administration mechanisms ${ }^{7}$ is not easy to capture in any model. Hence, this study provides a review of TRQ administration systems globally to provide further context.

\subsection{Global TRQ Policy Expectations and Permitting Systems}

Nagurney et al. (2019) explain that the world trade policy of TRQs is motivated by a national desire to protect domestic firms from competition and to reduce the domestic impact of such competition. The framework for the TRQ policies aimed at the agricultural trade is contained in the Agreement on Agriculture (AoA), which was negotiated during the Uruguay Round of trade negotiations and came into force in 1995 (WTO 2003). Agricultural products are defined in Article 2 of the AoA and the TRQ administration provisions to deal with the identified agricultural products are contained in the Ministerial Decision WT/MIN(13)/39 of the 2013 WTO Bali Ministerial Conference (WTO 2003, 2013b). TRQ administration as explained in WTO (2013a) refers to the methods used by governments to share quotas or quota licenses amongst traders. In the early 2000s, Gervais and Surprenant (2000) noted that some available studies indicated that the procedures to allocate licenses are arbitrarily chosen by the concerned countries. A WTO report explains that TRQ administration under the AoA was left to the importer countries to implement as they deemed appropriate, further noting that the TRQs had not improved market access for developing countries (WTO Committee on Agriculture 2000). Perhaps a rectification in recent times is what Beckman et al. (2017) describe, which is that in 2013, the rules for quota administration were brought under the WTO Agreement on Import Licensing Procedures (AILP). The rules as given under the AILP are expected to maintain some formality. The Bali Ministerial Decision WT/MIN(13)/39 categorised TRQ administration as a process 
of import licensing. Thereafter, consensus was reached that the AILP would be fully applied in dealing with TRQ administration. The AoA together with the AILP indicate the following desiderata of a TRQ administration system: that it should be transparent, predictable, uniform, non-discriminatory, and fair, with clearly specified timeframes and published explanation by the governing authority of the granting of licenses and how they are granted, and mandating countries administering the licensing should notify the WTO of the procedures followed as well as any changes to the procedures. Though the TRQ administration system is deemed central to the filling of quotas, it is widely acknowledged that the AoA does not give a directive of what TRQ administration methods to use (WTO Committee on Agriculture 2000). Recognising the long-standing issue of TRQ under-fill, the Ministerial Decision also refers to mechanisms proposed to deal with under-fill (WTO 2013b; Jatkar and Mukumba 2014).

TRQ administration mechanisms can be identified by various methods detailing their manner of implementation. Currently, seven principal TRQ administration methods have been identified in a report of the WTO Committee on Agriculture (WTO Committee on Agriculture 2018). TRQ administration includes methods such as a first-come, first-served system; licenses on demand; auctions; state trading and, domestic purchase requirement (Barichello 2000; Skully 2001; WTO 2003; Khorana 2008). Export history and the TRQ usepercentages reported by exporters are also among the aspects considered in administering TRQs (Khorana 2008). Barichello (2000) noted that there is sometimes discrimination against new entrants based on historical allocations. Khorana (2008) indicated that a combination of the different TRQ administration methods stated above can be used in one particular administration system. The practise of combining TRQ administration methods has been criticised for creating mechanisms that are complicated and non-transparent (Khorana 2008; Lim and Babula 2013). Lim and Babula (2013) further note that the method of auctioning is considered a transparent TRQ administration method and is deemed to promote high quota fill rates. Joerin (2014) discusses TRQ auctions from the point of view of the importer and argues that TRQs should only be allocated in an auction system, because this system prevents rent-seeking behaviour where firms have interests in gaining quota rents. ${ }^{8}$ The theoretical literature on TRQs, such as Miranda et al. (2010), suggests that they could be beneficial to exporters in improving market access and thus be welfare improving for both exporters and the consumers of the imported products. The notion of welfare improvement is grounded in the Bali Ministerial Decision WT/MIN(13)/39, which states that TRQ administration measures should ensure consistency with Article 3.2 of the AILP. In that disposition, the decision states that "importing Members shall ensure that unfilled tariff quota access is not attributable to administrative procedures that are more constraining" (WTO 2013b). The amenability of a TRQ administration system to such measures as stated in the AILP is thus important in furthering the goal of market access for exporters. The key question to therefore ask about TRQs provided under a free trade agreement, is whether the TRQ will be filled to ensure the full market access benefits.

The methods of TRQ administration give insights into the quota fill possibilities. The extent of fill of TRQs has been allied to a TRQ administration system in studies such as Herrmann et al. (2001), Monnich (2003), Miranda et al. (2010), and Loi et al. (2016). In an evaluation of TRQ fill rates, Monnich (2003) indicated that quota administration can be influential in quota fill. In a different study, Lim and Blandford (2009) found that quota administration methods significantly influence fill rates. In a report on the Swiss agricultural sector, Loi et al. (2016) indicated that nearly all of the 28 TRQs administered through methods that include auctioning, requirements on domestic purchases, historical imports, and first-come, first-served were filled. Loi et al. (2016) further indicate that TRQs and their administration system influence the quality composition of imports and their price. The occurrence of persistent under-fill is dependent upon a TRQ administration system and such under-fill is observed for most of the TRQ administration methods with the exception of the method considering historical imports as illustrated in the WTO Committee on Agriculture reports (WTO Committee on Agriculture 2013, 2018). There are 
some contradictions, therefore, in the literature concerning under-fill of TRQs in relation to the historical imports administration method.

Beckman et al. (2017) reported that fill rates recorded across all WTO notified TRQs were at an average of 59\% in 2013 and that concerns raised through the WTO Committee on Agriculture were dominated by TRQ under-fill concerns. In support of these concerns, some studies (Bendini et al. 2013; Beckman et al. 2017) have shown that TRQs provided through obligations of a free trade agreement do not translate into full market access improvements because of unfilled quotas. The EU was identified in Bendini et al. (2013) to be among the WTO members classified as having a persistent under-fill of TRQs meaning that TRQ fill rates were below $65 \%$ for three consecutive years. The WTO Committee on WTO Committee on Agriculture (2018) indicated an average fill rate of 57\% in 2016 across all TRQs notified to the WTO. Unfilled TRQs mean that planned exports differ from actual exports where actual exports are lower than the guaranteed quota level.

The literature cited above relates to TRQ analysis on the importer side. There is scant literature on the export side studies relating to exporter-administered TRQs that detail the methods used in the distribution of the rights to export. Even though the use of TRQs is prevalent in trade agreements globally, published research on TRQs is still limited, especially in relation to the agreements signed between African countries and the European Union. In addition, the available studies (Monnich 2003; Khorana 2008; $\mathrm{Li}$ and Carter 2009) aside from not focusing on South Africa or Africa, researched TRQ administration on the importer side. This paper therefore fills the study gap by describing the TRQ administration system implemented by DAFF/DALRRD to manage exporter access to the EU fruit products (that include the canned fruits TRQ) markets and by so doing, sets the context for the assessment of tariff line coverage and fill rates. An illustrative case of the exporter administered TRQ system in the South African case is presented in the results section.

\subsection{Summary of Previous Studies Modelling Welfare Impacts of TRQs}

Various studies (Drogue and Ramos 2005; Decreux and Ramos 2007; Tsigas and Mora 2009; Meade et al. 2010; Narayanan et al. 2010; Bektasoglu et al. 2011) employed CGE as well as partial equilibrium (PE) models to analyse TRQ impacts. Particular studies such as Decreux and Ramos (2007) and Meade et al. (2010) indicated that welfare gains were realised in greater portion for out-of-quota tariff liberalisation than quota expansion and the opposite was found in van der Mensbrugghe et al. (2003). Bektasoglu et al. (2011) reported higher welfare changes when import tariffs were liberalised in a model with disaggregated sectors than a model with aggregated sectors. Economic loss on welfare has also been observed for the importer countries granting a TRQ and gains have been observed for the countries receiving a TRQ preference, but the level of welfare gains differs across sectors (Tsigas and Mora 2009; Meade et al. 2010).

\section{Methodology}

A case study of South Africa's pear, apricots, and peaches TRQ (referred to in this study as the canned fruits TRQ) was selected for its strategic export value importance among fruit products TRQ exports of South Africa to the EU. The canned fruits TRQ case was used as the basis for describing the exporter administered TRQ permit allocation system, assessing TRQ coverage in terms of the number of tariff lines included, analysing TRQ fill rates as well as the welfare effects associated with the TRQ liberalisation policy. The welfare effects measured in equivalent variation (EV) were analysed to compare performance in two scenarios of a filled and an unfilled TRQ. Following the description of data sources in Section 3.1, the data analysis methods are presented in Section 3.2. Figure 1 presents the framework contextualising the analysis of TRQ performance in this study. 


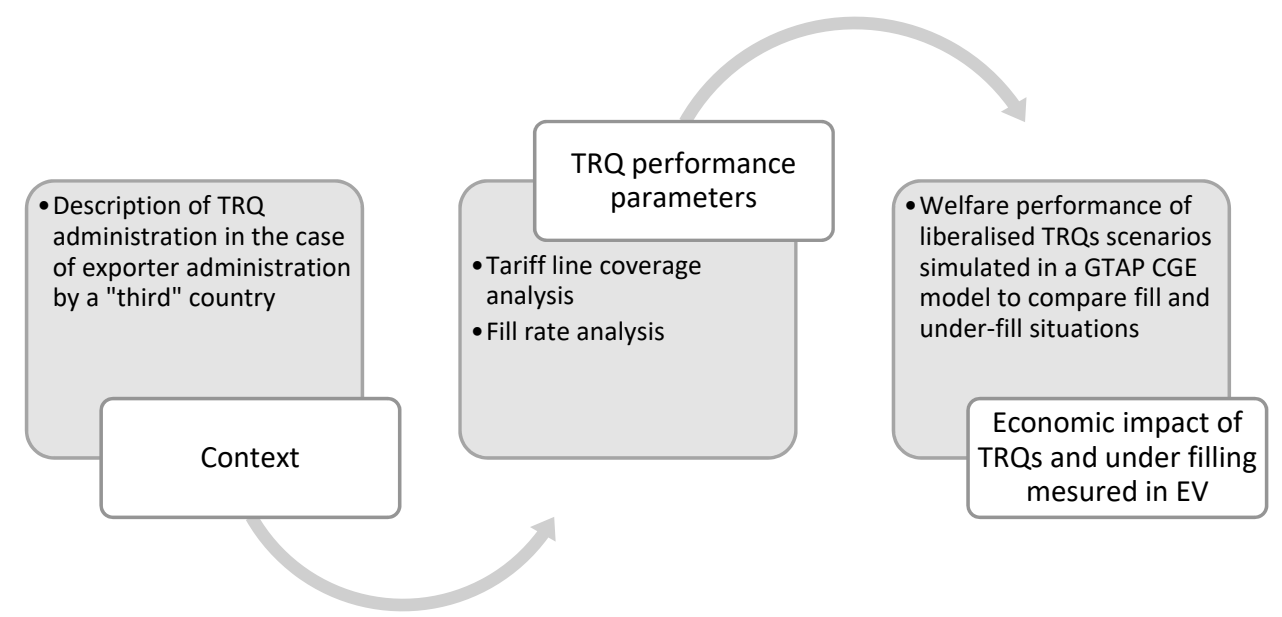

Figure 1. Framework contextualising the analysis of TRQ performance.

\subsection{Data Sources}

Secondary data were collected from two main sources, namely the Integrated Tariff of the European Union (TARIC) database and the Global Trade Analysis Project (GTAP) database version 9. The TARIC database provides annual reports on quota volumes for each TRQ that the EU has offered bilaterally and/or openly offered to all countries. The GTAP 9 database utilised in this study has the world economy represented for three different years, namely 2004, 2007, and 2011, and represents bilateral trade for 114 regions and 57 sectors. The GTAP 9 database reference year 2011 was the source of the bilateral trade flows of the TRQ exports analysed in this study. The exports were recorded at the HS 6-digit code where the codes HS2008.40; HS2008.50, and HS2008.70 identify the tariff lines relating to pears/apricots/peaches. Given that there are 114 regions in the model, and that the model is not a "plug and play" or an "off the shelf use", a step to aggregate the regions was undertaken to prepare the database to suit the problem being analysed in this study. To this end, the GTAPAgg software in combination with SplitCom (a GTAP utility) was used to aggregate the GTAP sectors to suit the analysis of the HS 6-digit code canned fruits TRQ enabling the introduction of the canned fruits TRQ as a standalone ${ }^{9}$ sector of the GTAP model. Three regions (South Africa, EU28, and the Rest of the World) were demarcated for analysis to enable the implementation of trade liberalisation scenarios of the bilateral trade between South Africa and the EU. Given that the GTAP 9 version of the model represents the economy of the world in 2011 (which is the year prior to the full implementation of the TDCA), in order to analyse the changes in 2019 (the year prior to the COVID-19 crisis), the model was projected from 2011 (the baseline) to 2019 using gross domestic product (GDP) growth rates data of the International Monetary Fund (IMF 2020)—World Economic Outlook (WEO) database of 2020. Following Burfisher (2011), cumulative GDP growth rates were calculated for the period 2012 to 2019 and simulated as the exogenous input shocks to model the expected economic conditions in 2019 for each of the three regions-South Africa, EU28, and the Rest of the World. Additional data to those which are available in the GTAP database were therefore used to project the static GTAP database to the year 2019 for analysis of the welfare effects of TRQ liberalisation.

\subsection{Data Analysis Methods}

The coverage of the canned fruits TRQ is first described by comparing the number of tariff lines (HS 8-digit disaggregated levels) pre and post the implementation of the SADC-EU-EPA followed by the analysis of the utilisation of the TRQ quota allocation, measured by fill rates. The fill rates were calculated on a yearly basis as a ratio of the level of actual exports to the total quota allocation of the canned fruits TRQ. The GTAP model (fully described in Hertel 1997), which is a computable general equilibrium (CGE) model (that enables economy-wide impact analysis), was relevant to analyse welfare effects from the 
TRQ liberalisation of canned fruits trade given that the model is the most commonly used model for analysing international trade liberalisation. In support of CGE models, Ciuriak and Chen (2007), indicated their suitability to compare the structure of the economy before and after a policy change simulation. To determine welfare effects, trade liberalisation simulations were carried out representing the under-fill and fill situations of the canned fruits TRQ. The first simulation involved the removal of the tariff in the existing case of the unfilled fruit products TRQ. The second simulation, which was implemented in two steps, involved first a shock to the quantity variable in the model to simulate a $100 \%$ quota fill level, followed by the removal of the tariff.

GEMPACK software was used in the modelling and the welfare effects were measured in equivalent variation (EV). Welfare change measured in EV was described as the change in money income that would produce the same effect on the country's utility as the policy shock (Plummer et al. 2011; Jensen and Sandrey 2013). In the static GTAP CGE model simulation, the EV measure is made up of predominantly the terms of trade and allocative efficiency effects. There is a welfare gain when EV is positive, and when it is negative, there is a welfare loss. Bowen et al. (2012) explained that CGE models perform the EV calculation by deriving the associated expenditure function from the assumed form of the utility function in the model and further illustrated that EV can be determined by finding the difference between the utility level that a country achieves under its current set of trade policy instruments and the utility level under a new set of trade policies. This is represented by the following equation:

$$
E V=S\left(P_{d}, P_{m}, P_{w}, U_{1}\right)-S\left(P_{d}, P_{m}, P_{w}, U_{0}\right)
$$

where:

$S=$ expenditure function,

$P_{d}=$ domestic price of domestic goods,

$P_{m}=$ domestic price of imported goods,

$P_{w}=$ world prices of domestic goods,

$U_{0}=$ country utility level at current trade policies, and

$U_{1}=$ country utility level under a new set of trade policies

\section{Results and Discussion}

This section describes and discusses the results drawn from the analysis conducted to establish the performance of the canned fruits TRQ. The discussion (in Section 4.1) of elements of the TRQ administration system adopted by DAFF helps to understand the interaction of the criteria of the administration system within the context of other studies that have assessed tariff line coverage and fill rates.

\subsection{TRQ Administration-The South Africa Context}

Trade under the TDCA occurred from 1999 to 2016 and at the end of 2016, the trade chapter of the TDCA was replaced by the Southern African Development CommunityEU-Economic Partnership Agreement (SADC-EU-EPA) which is currently in force. The terms of the agreements are the same regarding the fruit products TRQ market access opportunity for South Africa in relation to implementation and management. The same permit allocation system prevails in the management of the TRQs of the SADC-EU-EPA. DAFF (now DALRRD) through its management of the TRQ permit allocation system is responsible for facilitating quota fill and ultimately market access. Given that WTO members with TRQs specified in their tariff schedules are required under WTO rules and principles to notify the WTO of TRQ administration and the volume of imports under TRQ management, the EU, with respect to the TRQs granted to South Africa, notified the WTO of the relevant TRQs from the importer perspective. However, the rules for notifying the WTO of TRQs do not require exporters (South Africa) to report TRQ administration. Could this be a shortcoming of the notification requirements? Whereas the TRQ administration system on the importer side is predisposed to hinder quota fill as a way to protect the 
domestic industry, exporter-administered TRQ permit systems may also indirectly lead to quota fill inhibition when not managed properly. In addition to TRQ administration, various factors that inhibit quota fill have been identified in literature and these include product competitiveness, in-quota tariff rates, quota level, low import demand, and supply constraints (Monnich 2003; Khorana 2008; Li and Carter 2009). These identified factors do not form part of the scope of analysis in this study.

The canned fruits TRQ is a country-specific tariff quota allocation by the EU to South Africa and the trade arrangement is such that South Africa administers the quota on the export side of the trade agreement. The information summarised here comes from South Africa's Government Gazette from various years (2010-2019). South Africa's administrative system for TRQs combines various aspects of different TRQ administration methods but the auction method is excluded. The mechanism to allocate all fruit products TRQ shares/permits is published annually in the South African Government Gazette announcing the available quota quantities as well as the procedures for application to obtain quota permits. This practise of publishing available quotas together with information on the procedures to apply for permits is consistent with the basic criteria on quota administration set out in the AILP and targeted at importer countries. The available quota for canned fruits that was published or announced annually for the selected years from 2010 to 2019 is presented in the Appendix A Table A2 (ranging between 53,446 tons in 2010 to 60,866 in 2016 and reduced to 57,156 tons in the period 2017-2019). Further analysis of quota fill for the canned fruits TRQ is presented in Section 4.2 and conclusions can be reached from the standpoint of improving market access.

To manage the TRQs, South Africa put in place a system of managing the distribution of export shares among applicants. At the institutional level of the fruit products TRQ management, DAFF/DALRRD manages the license/permit allocation in collaboration/consultation with umbrella associations in the canned fruit and fruit juice sub-sectors which are the main beneficiaries of the fruit products TRQs market access opportunity. The South African Fruit and Vegetable Canners Association (SAFVCA) is the association that assists DAFF/DALRRD in allocating permits for the canned fruits TRQ. The collaboration is in terms of the assessment of quota use and administration as it relates to the members of SAFVCA. Given that member associations such as producer groups are tasked with serving member interests, those interests may not apply to many exporters outside the membership of the association and to this end, the fairness of the administration criteria may not be upheld. In general, it can be envisaged that an efficient TRQ system is administered in such a way as to encourage many exporters and no monopoly.

The applicants are categorised in terms of their export history. DAFF/DALRRD distinguishes between exporting companies with three or more years of exporting history and those with less than three years. The historical exporter of three or more years can apply for larger quantities. This method of considering historical imports has been criticised in Lim and Babula (2013) as a less transparent method of administering TRQs. Another layer in the criteria followed to allocate fruit products TRQ export shares has a basis in the Broad Based Black Economic Empowerment (BBBEE) scoring. BBBEE scoring, which as a policy aims at redressing some imbalances of the past regarding economic opportunities, has been included in the criteria as a way to promote accessibility of export shares in the fruit products TRQs. The nature of this practice does not provide enough detail to ascertain whether it violates the non-discriminatory criterion or obligation in administering TRQs. Special consideration is also given for new exporters and emerging exporters as indicated in the application procedures. Permits are allocated to applicants in two rounds annually, where the first-round targets BBBEE rated as compliant applicants and in the second round, reallocation of unused quota shares is carried out and BBBEE non-compliant applicants are included. The allocation of permits to applicants therefore considers the applicant's status in terms of historical export advantages/disadvantages, the applicant's desired quota quantity, and the available annual quota against the number of prospective applicants (Parliament of Republic of South Africa 2013; South Africa. Government Gazette 2014, 
2015, 2018). In assessing this reallocation process, the information available does not imply that evidence is adduced on historic performances and supply capabilities, leaving the question of whether the administration procedure enables predictability on TRQ allocation. Lim and Babula (2013) consider the use of producer groups coupled with the historical allocation of quota shares to be less transparent as a method of administering TRQs.

The TRQ permit allocation system in South Africa described above could be consequential on the capacity of full quota use by quota holders. The level of an applicant's BBBEE compliance dictates the allocation amounts and it is not surprising therefore to find that an applicant may obtain the least share regardless of the applicant's export capabilities. Although the allocation of quota that is based on the BBBEE scoring has the intention to rationalise access to TRQ export quotas for the South African players, the system indirectly or unintentionally restricts the quota amounts to capable exporters, consequently with negative impacts on the filling of quotas. Even though the second-round reallocation of unused quotas includes BBBEE non-compliant applicants and possibly the historically advantaged applicants that had not received the full amount for their share application, there is no guarantee that underutilisation of quotas will be avoided. Exporters naturally deal with the uncertainty of access to TRQ export permits by making alternative decisions on exporting available stock to other available destinations to avoid a total loss of export revenue. Barriers presented through TRQ export permit allocation procedures cannot therefore be ruled out among other factors impacting TRQ fill. Thus, the inability to fill TRQs is not entirely attributable to the lack of supply, deficient import demand, or tariff levels. Literature such as Hasha (2004) and CBI (2015) asserts the existence of EU import demand for fruit and vegetables noting that the EU import regime runs at a deficit. On the other hand, Beckman (2021) notes that the WTO members often question EU quota allocations on fruits among other commodities such as vegetables and meat.

The market access performance under a trade agreement is measured in terms of quota fill (Beckman 2021), thus the quality of the TRQ permit system in administering export quotas is vital. The AILP places emphasis only on importing countries, leaving the exporteradministered TRQs in the hands of the exporters to govern the transparency and efficiency of their systems. However, assessing the South African TRQ administration system against the stipulations of the AoA and AILP obligations, it seems that the administration criteria are largely complied with. Historical allocations as the basis to allocate permits may be the hindrance to new entrants accessing the canned fruits TRQ. Such discrimination that may arise was long ago asserted in the study of Barichello (2000).

The importance of a trade agreement should not be spotlighted only by successful negotiations and the agreement's coming into force. The negotiated market access has to be utilised fully to deem the agreement a success. The TRQ concessions are not an end but a means to access the market, with the added expectation of improved welfare effects due to the TRQ liberalisation policy. The number of tariff lines combined in a TRQ as well as TRQ fill rates are the selected performance parameters considered in this study within the context of the TRQ administration system. Given that the competencies of a TRQ administration system in ensuring quota fill have not been established in this description of the present study and that administration methods do not indicate how the TRQ liberalisation policy has wholly performed, further analysis of the welfare effects of the canned fruit TRQ was undertaken in this paper to analyse TRQ performance.

\subsection{Tariff Line Coverage and TRQ Fill Rate Analysis}

The number of tariff lines (defined at the HS 10-digit code) included under the canned fruits TRQ increased from 63 (prior to the SADC-EU-EPA implementation) to 72 tariff lines (after the implementation of the SADC-EU-EPA). Therefore, the transition from the TDCA to the SADC-EU-EPA expanded the tariff line coverage by an additional 9 tariff lines. Figure 2a illustrates the annual increase of the TRQ volume from 2010-2016. The fill rate analysis is also presented in Figure 2a. 
(a)

Canned fruits available TRQ allocation and fill rates (2010-2019)

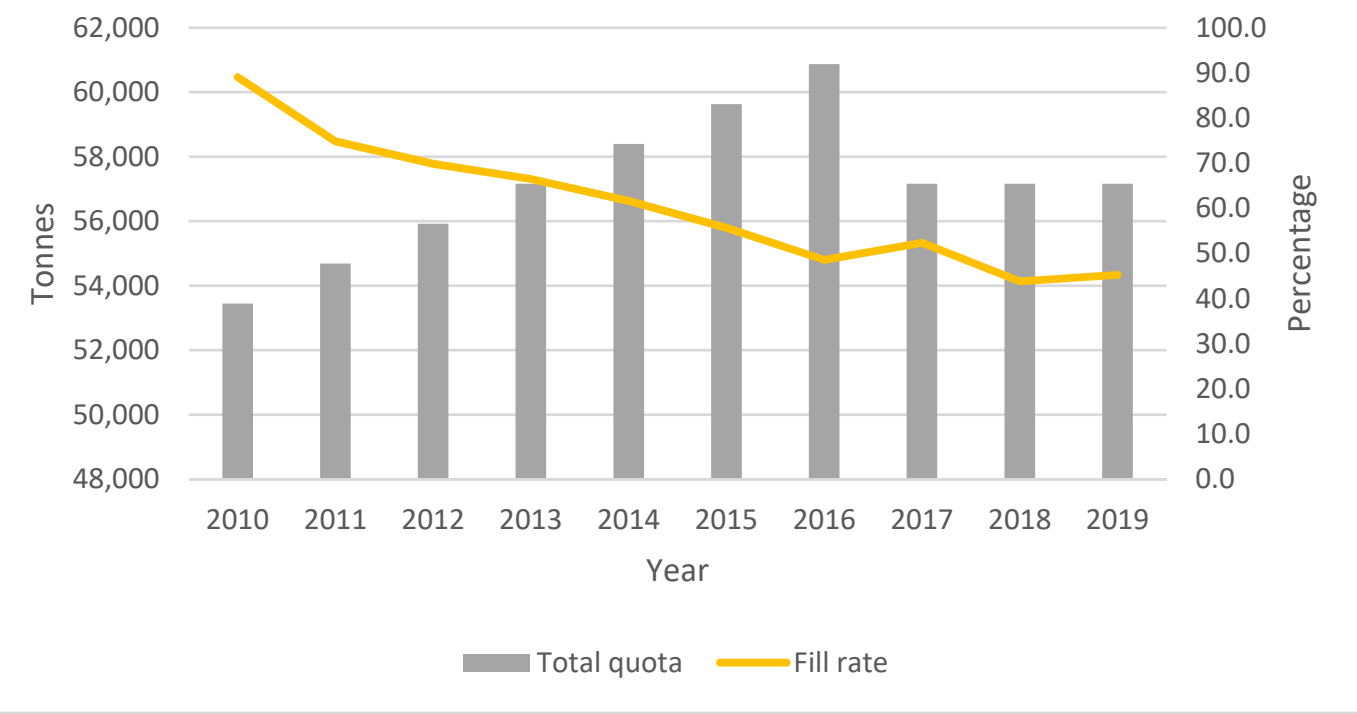

(b)

\section{Canned fruits TRQ usage (2010-2019)}

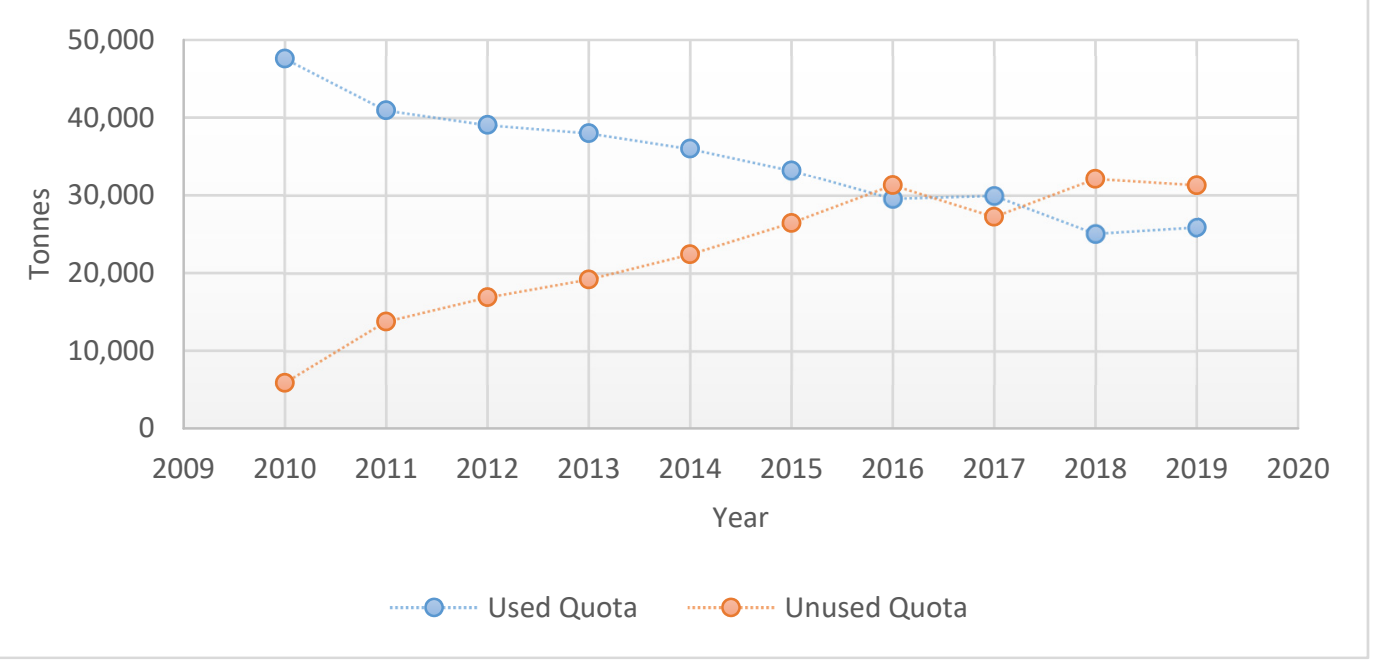

Figure 2. Canned fruits TRQ. (a) Yearly available quota and fill rates; (b) yearly used and unused quota.

The allocated quota was increased annually and reached a peaked in 2016 before the quota was reduced and capped at 57,156 tonnes at the onset of the SADC-EU-EPA. The volume of actual exports (illustrated as used quota in Figure 2b) consistently decreased from 2010 to 2019 (with only a slight uptick in 2017). The constantly decreasing fill rates from as high as $80 \%$ in 2010 to below 50\% in 2019 illustrate the decreased performance of the TRQ as a tool for improved market access. Though the quota limits had been annually increased up to 2016, culminating with a broadened tariff line coverage from the end of 2016, that action did not result in increased fill rates nor any out-of-quota exports for the subsequent years. This suggests that not all the tariff lines included in the TRQ are utilised by exporters, thus failing to take advantage of the export market access opportunity. The unfilled canned fruits TRQ resonates with the case noted in Bendini et al. (2013), also noted in Beckman et al. (2017), that TRQs provided through a trade agreement have not translated into full market access. 
The TRQ level in 2013 (which is the year after the full implementation of the TDCA) seems to have dictated the level of cap for the TRQ from 2017 onwards. At exactly the same level of quota, the fill rate in 2013 was about $66 \%$ compared to the $52 \%$ in 2017 and less than 50\% for both 2018 and 2019. The results conform with the WTO Committee on WTO Committee on Agriculture (2020) report which found average fill rates for all TRQs taken into account for 2019 to be $46 \%$. Therefore, this highlights that the under-filled canned fruits TRQ may not be an isolated problem, but a global issue for the TRQ policy. The year 2013 was the last year on record for which the fill rate for the canned fruits TRQ was close to $65 \%$. The canned fruits exports currently under the SADC-EU-EPA have therefore failed to reach the TDCA levels of 2013 implying that the performance of the TRQ has worsened further in the wake of the reduced market access opportunity to the EU market that has been imposed through the capped TRQ. These findings indicate that the TRQ was performing above the average fill rate of 59\% for all WTO notified TRQs in 2013 as reported in Beckman et al. (2017). However, by 2016, the fill rate of $48.6 \%$ was below the reported WTO average of 57\% (WTO Committee on Agriculture 2018) across all TRQs. Comparing the fill rate of 2013 to the years 2017, 2018, and 2019 (all capped at 2013 quota levels), the performance in terms of fill rates declined further indicating that the cap on the TRQ can be justified in line with the rules of market access provisions under the WTO obligations, which stipulate that persistently under-filled quotas should be released and be reallocated. More tariff lines included in the canned fruits TRQ after the TDCA period should lead to better fill rates under the SADC-EU-EPA because the opportunity is broadened, but this has not been the case.

The period preceding 2016 depicts an interesting picture that can be associated with the impending end of the TDCA and beginning of the SADC-EU-EPA. There was a steady decrease in the used quota which reached the lowest level in 2016 illustrated in Figure $2 \mathrm{~b}$. Uncertainty of future trade prospects may have caused the slight uptick in 2017 as exporters anticipated some change to the rules. Past that period, the same pattern of persistent under-fill was observed. The manner of allocation of permits (detailed in Section 4.1) where for the first round, a certain portion of permits are reserved for BBBEE-compliant companies might unintentionally trigger the exporters with stock but no permits to redirect their stock or seek alternative export markets. In the reallocation phase, the likelihood that there is reduced or no supply capacity is therefore plausible.

One of the criteria in administering the canned fruits TRQ is the consideration of historical imports (dating back 3 years). As evident from the study results, the TRQ was still not filled under the circumstances. These findings are in contrast to the study of Loi et al. (2016) that indicated that historical import considerations as part of administration methods have led to filled quotas. A WTO Committee on Agriculture (2019) report of the Committee on Agriculture, also in contrast to this study's findings, highlighted that on average (2007-2016), the historical importation method had the highest fill rate compared to other methods of TRQ administration, further noting that a $100 \%$ fill rate was recorded on imports administered through the method of historical imports by Australia, Mexico, and Switzerland. The contrasting findings could be explained by this study having analysed an exporter-administered TRQ whereas the other studies analysed TRQ administration by the importer.

In summary, this study's findings on tariff line coverage and the associated fill rates, within the context of an exporter-administered TRQ system, demonstrate the argument advanced in de Gorter and Sheldon (2001) that when the TRQ is defined across a narrow category and covering a limited number of tariff lines, that might impact the fill rates. As indicated in Section 4.1, the notices for application to obtain TRQ permits indicate in most instances HS 8-digit codes but at administrative level, the EU has set tariff lines that are valid for the canned fruits TRQ at greater specificity of the HS 10-digit level. The broad categories such as HS 4-digit or HS 2008.40/50/70 at the 6-digit level would maximise access as there would be no further constraints for each category compared to the HS 10-digit level definitions of the allowed products used by the EU. 


\subsection{Welfare Results}

The study analysed the full (100\%) tariff liberalisation (i.e., the new set of policies set as $U_{1}$ in Equation (1)) of the canned fruits TRQ and the results of the two liberalisation experiments are reported in Table 1. Welfare effects of an unfilled quota set against the ideal situation of a filled quota were assessed and the welfare change results measured $n$ $\mathrm{EV}$ are presented for all three regions in the model, but the main conclusions were drawn for South Africa, which is the region of focus in this paper. The simulated welfare results were assessed based on the complete removal of the in-quota tariff.

Table 1. Simulated welfare results for a $100 \%$ tariff liberalisation.

\begin{tabular}{ccc}
\hline \multirow{2}{*}{ Region in the Model } & \multicolumn{2}{c}{ EV Measured in Million USD } \\
\cline { 2 - 3 } & Unfilled Quota & Filled Quota \\
\hline South Africa & 0.002497 & 0.002530 \\
EU & 0.000126 & 0.000043 \\
Rest of the World & -0.00051 & -0.00052 \\
\hline
\end{tabular}

Source: GTAP model results.

There is a positive welfare change under both liberalisation scenarios (filled and unfilled TRQ) for South Africa as well as the EU, confirming that the in-quota tariff acts as an added barrier to exports and this is widely acknowledged and supported in various trade literature such as WTO Committee on WTO Committee on Agriculture (2000) and Monnich (2003). The results of welfare improvement in both South Africa and the EU are therefore according to prior expectations. The findings are also supported in Miranda et al. (2010), noting that TRQs are welfare improving for both exporters and importers. In addition, and as can be expected for South Africa, the filled quota scenario presents a higher (USD 2530) welfare change than the unfilled quota scenario (USD 2497) implying that not all the market access benefits have been gained by South Africa given the status quo of the unfilled quota. The prevailing unfilled quota situation for the canned fruits TRQ has led to the achievement of less than the total welfare gains available under the new trade conditions. The filled quota scenario is ideally the scenario that grosses the full benefits from the advantage offered by the TRQ market access opportunity. Such a finding is consistent with the observation in van der Mensbrugghe et al. (2003) that welfare gains are realised in greater proportion under quota expansion.

A filled quota with a zero in-quota tariff rate, importantly, is a source of higher welfare gains than an unfilled quota and the source of these gains is linked to a change in prices. In the results presented in Appendix A Table A3, it can be seen that the full tariff liberalisation leads to a price decrease of $8.5 \%$ in the domestic price of canned fruits imported from South Africa to the EU. The export sales of canned fruits from South Africa to the EU increase by $34 \%$ and the industry output of canned fruits in South Africa increase by $0.04 \%$. The low industry output in South Africa therefore does not fully support the increased exports potential and this could be the bottleneck that in the long run also leads to quota underfill. The increased exports observed from the simulation are consistent with economic intuition following a price decrease such as that simulated in the EU market after a full tariff liberalisation. Notably, the increased exports after the simulation experiment are a likely contributor to the positive welfare, implying that the trade policy negotiators should aim to negotiate for complete removal of in-quota tariffs for the canned fruits TRQ. The findings of this study are consistent with Bektasoglu et al. (2011). The results on quota usage and quota fill analysis showed a decline in performance of the TRQ, hence, aside from the tariff, other non-tariff barriers such as standards could be contributing to quota under-fill. This is an area for further studies to determine the standards that may be presenting as barriers to trade flows. 


\subsection{Robustness Check}

A systematic sensitivity analysis was performed to check the sensitivity of the results in response to changes in shocks to the model. The means and standard deviations were calculated for the endogenous variables of the model and selected results are presented in Table A4 in the Appendix A. After allowing for the variation in the shock to the tariff in both filled and unfilled scenarios, the results for the selected endogenous variables were significant at 95\% confidence level, indicating that the simulation results are robust.

\section{Conclusions}

This paper described the TRQ administration system from the exporter administration perspective, highlighting the criteria applied idem under the TDCA and the SADC-EUEPA. The main changes in the trade conditions from the TDCA to the SADC-EU-EPA and relevant for the canned fruits TRQ are the cap on the TRQ (no annual increments), the inquota tariff reduction, and the expanded tariff line coverage of the TRQ. The performance of the TRQ has largely been below par in comparison to average fill rates of TRQs notified at the WTO. The TRQ administration that reserves certain portions for BBBEE beneficiaries makes the filling of quotas to be inefficient. At the country level, given the persistent underfill, there is little justification for restricting permit allocations based on BBBEE principles. Uncertainty arises among applicants whenever there are no guarantees for acquiring quota export permits. Considerations should therefore be made to allocate the full quota applied for by an applicant in the first cycle of applications as long as the total requested quota by all applicants does not exceed the available quota. This would reduce the level of uncertainty that may lead to a decision by an applicant to supply alternative markets. The anticipated effect of a new trade agreement is improved market access, and a filled quota would enhance the trade gains. Had South Africa's canned fruits TRQ not been capped, on a global level, the situation would have perpetuated the inefficiency that arises where quotas are allocated to non-users as may be dictated within bilateral trade agreements. However, there is still scope to further liberalise trade through the complete removal of tariffs and this scenario was therefore simulated to gain an understanding of what is likely to happen in terms of trade gains measured in welfare. Welfare effects of tariff liberalisation of the canned fruit products TRQ were quantified using the GTAP model and reported as an EV measure of economic welfare changes. The filled TRQ improves welfare more than the unfilled TRQ. The results have demonstrated that full tariff liberalisation improves welfare and the benefits are larger for a filled TRQ. The welfare gains, though modest, indicate that the filled TRQ has a better performance; hence, the TRQ administration system should be designed to promote quota fill. Policies such as the TRQ policies are meant to give incentives to the exporters; hence, the policy makers need to ensure an enabling environment that allows exporters to utilise the market access opportunity.

Funding: This research received no external funding.

Acknowledgments: The author acknowledges comments received in the process of developing the paper concept at a Kerlick Workshop organized by the University of Limpopo.

Conflicts of Interest: The author declares no conflict of interest. 


\section{Appendix A}

Table A1. EU imported value of fruit products from South Africa (2011-2019)—EUR.

\begin{tabular}{|c|c|c|c|c|c|c|c|c|c|}
\hline $\begin{array}{c}\text { TRQ } \\
\text { 6-Digit HS Code }\end{array}$ & 2011 & 2012 & 2013 & 2014 & 2015 & 2016 & 2017 & 2018 & 2019 \\
\hline $\begin{array}{c}\text { Pears, apricots, and peaches } \\
\text { HS2008.40/.50/.70 }\end{array}$ & $36,274,223$ & $38,448,413$ & $39,057,586$ & $37,628,871$ & $31,467,951$ & $29,233,394$ & $29,852,555$ & $22,762,986$ & $26,296,306$ \\
\hline $\begin{array}{l}\text { Strawberries } \\
\text { HS } 0811.10\end{array}$ & 0 & 0 & 0 & 0 & 0 & 0 & 6105 & 0 & 13 \\
\hline $\begin{array}{l}\text { Mixtures of fruit * } \\
\text { HS2008.97 }\end{array}$ & & $5,788,307$ & $6,188,509$ & $4,684,266$ & $2,889,246$ & $2,792,839$ & $2,632,205$ & $2,529,164$ & $4,017,844$ \\
\hline $\begin{array}{l}\text { Frozen orange juice } \\
\text { HS2009.11 }\end{array}$ & $1,026,901$ & 683,867 & 882,476 & $2,118,048$ & $1,278,329$ & $1,024,564$ & 665,146 & 786,262 & 992,328 \\
\hline $\begin{array}{c}\text { Pineapple, apple juice } \\
\text { HS2009.41/.49 } \\
\text { HS2009.71/.79 }\end{array}$ & $7,922,095$ & $2,538,197$ & $1,767,951$ & $2,592,689$ & $4,867,618$ & $10,608,745$ & $5,219,826$ & $8,252,380$ & $5,085,484$ \\
\hline Total value (EUR) & $45,223,219$ & $47,458,784$ & $47,896,522$ & $47,023,874$ & $40,503,144$ & $43,659,542$ & $38,375,837$ & $34,330,792$ & $36,391,975$ \\
\hline $\begin{array}{l}\% \text { contribution of the pears, } \\
\text { apricots, peaches TRQ }\end{array}$ & 80 & 81 & 81 & 80 & 78 & 67 & 78 & 66 & 72 \\
\hline
\end{tabular}

Source: Author's calculations based on European Commission (2020). ${ }^{*}$ The canned fruit mixtures of fruit were granted under 2 TRQstropical and non-tropical.

Table A2. Allocated quota and fill rates (2010-2019) for the pears, apricots, and peaches TRQ.

\begin{tabular}{ccccccccccc}
\hline & $\mathbf{2 0 1 0}$ & $\mathbf{2 0 1 1}$ & $\mathbf{2 0 1 2}$ & $\mathbf{2 0 1 3}$ & $\mathbf{2 0 1 4}$ & $\mathbf{2 0 1 5}$ & $\mathbf{2 0 1 6}$ & $\mathbf{2 0 1 7}$ & $\mathbf{2 0 1 8}$ & $\mathbf{2 0 1 9}$ \\
\hline Total quota (tons) & 53,446 & 54,682 & 55,919 & 57,156 & 58,393 & 59,630 & 60,866 & 57,156 & 57,156 & 57,156 \\
Fill rate (\%) & 89.0 & 74.9 & 69.8 & 66.5 & 61.6 & 55.7 & 48.6 & 52.4 & 43.8 & 45.3 \\
\hline
\end{tabular}

Source: Author's calculations and TARIC database.

Table A3. Simulation results for selected outcome variables.

\begin{tabular}{|c|c|c|c|c|c|c|}
\hline \multirow[b]{2}{*}{$\begin{array}{l}\text { Domestic price for canned fruits } \\
\text { supplied from region } r \text { to } s \\
R=\text { row, } s=\text { column }\end{array}$} & \multicolumn{3}{|c|}{$\begin{array}{c}\text { Experiment 1-Unfilled Quota, 100\% Tariff Liberalisation } \\
\text { (\% Change) }\end{array}$} & \multicolumn{3}{|c|}{$\begin{array}{c}\text { Experiment 2-Filled Quota, 100\% Tariff Liberalisation } \\
\text { (\% Change) }\end{array}$} \\
\hline & SOUTH_AFRICA & EU_28 & Rest of the World & SOUTH_AFRICA & EU_28 & Rest of the World \\
\hline SOUTH_AFRICA & 0.000026 & -8.500278 & 0.000024 & 0.000003 & -8.5003 & 0.000003 \\
\hline EU_28 & -0.000001 & -0.000001 & -0.000001 & 0 & 0 & 0 \\
\hline Rest of the World & 0 & 0 & 0 & 0 & 0 & 0 \\
\hline $\begin{array}{l}\text { Export sales for canned fruits } \\
\text { supplied from region } r \text { to } s \\
R=\text { row, } s=\text { column }\end{array}$ & SOUTH_AFRICA & EU_28 & Rest of the World & SOUTH_AFRICA & EU_28 & Rest of the World \\
\hline SOUTH_AFRICA & 0.000013 & 33.952953 & -0.000011 & 0.000013 & 33.95247 & -0.000011 \\
\hline EU_28 & 0.000025 & -0.048238 & 0.000001 & 0.000025 & -0.04872 & 0.000001 \\
\hline Rest of the World & 0.000024 & -0.048239 & 0 & 0.000025 & -0.04872 & 0 \\
\hline \multicolumn{7}{|c|}{ Industry output for canned fruits } \\
\hline SOUTH_AFRICA & & 0.037334 & & & 0.037833 & \\
\hline EU_28 & & -0.001135 & & & -0.001146 & \\
\hline Rest of the World & & -0.000038 & & & -0.000038 & \\
\hline
\end{tabular}

Source: GTAP model results.

Table A4. Systematic sensitivity analysis.

\begin{tabular}{|c|c|c|c|c|c|c|c|c|}
\hline \multirow{3}{*}{ Endogenous Variable } & \multicolumn{4}{|c|}{ Experiment 1-Unfilled Quota, 100\% Tariff Liberalisation } & \multicolumn{4}{|c|}{ Experiment 2-Filled Quota, 100\% Tariff Liberalisation } \\
\hline & \multirow{2}{*}{ Mean } & \multirow{2}{*}{$\begin{array}{l}\text { Standard } \\
\text { Deviation }\end{array}$} & \multicolumn{2}{|c|}{ 95\% Confidence Interval } & \multirow{2}{*}{ Mean } & \multirow{2}{*}{$\begin{array}{l}\text { Standard } \\
\text { Deviation }\end{array}$} & \multicolumn{2}{|c|}{ 95\% Confidence Interval } \\
\hline & & & Min & Max & & & Min & Max \\
\hline Output in South Africa & 0.037334 & 0.007621 & 0.00326813 & 0.07139987 & 0.03795 & 0.007723 & 0.00342819 & 0.07247181 \\
\hline Exports for South Africa to EU & $3,395,295$ & $6,930,618$ & $2,973,091$ & $6,493,282$ & 339,524 & $6,930,518$ & $297,296,154$ & $649,317,924$ \\
\hline EU import prices & -0.02381 & 0.00486 & -0.04553 & -0.00209 & -0.02405 & 0.004909 & -0.04599223 & -0.0021058 \\
\hline
\end{tabular}




\section{Notes}

1 Canned fruits are among a list of products included by the EU under its list of "sensitive agricultural products". Sensitive agricultural products are mainly viewed as products that require the protection of local producers from import competition. Such sensitive products, as observed in Perez and Jallab (2009), are the lines of products that are then ordinarily exempted from liberalisation. They are of strategic national importance, normally incur high tariffs, and their importation is conditional on supply management policies, as argued in Pouliot and Larue (2012).

2 The EU28 before BREXIT.

3 The EU TDCA offer to South Africa for the canned pears, apricots, and peaches comprises 3 tariff lines combined under a single TRQ. TRQ commitments are administered at different levels of commodity aggregation (Barichello 2000). In addition, a TRQ commitment can be defined across a broad commodity category (aggregated) such as fruits (HS 4-digit level), whereas in administrative terms, a TRQ is defined for specific (disaggregated) HS 6- or HS 8-digit level tariff lines differentiating various forms of product of a single HS 4-digit level commodity.

4 The government in South Africa, specifically through DAFF (now the Department of Agriculture, Land Reform and Rural Development (DALRRD)), is involved in managing TDCA/SADC-EU-EPA fruit products exports through the allocation of export permits that enable exporters to access the EU market.

5 https://www.bbc.com/news/54152583 (accessed on 5 September 2021).

6 The World Customs Organisation (WCO), which developed the system of HS codes, describes the HS as a universal economic language and code for export goods that are internationally traded. Specific HS 6-digit codes are assigned to different variations of commodities (WCO 2019). The six fruit products of the TDCA comprise 10 tariff lines when defined at the HS 6-digit code.

7 TRQ administration mechanisms are explained in Section 2.

8 Quota rents are an economic welfare measure that are calculated by multiplying the quantity of the quota by the price difference between the world price plus in-quota tariff and the domestic price of the imported product (Lim and Babula 2013).

9 In the standard GTAP database, the canned fruit products are part of the sector referred to as "other fruit products".

\section{References}

Abbott, Philip. C., and Phili. L. Paarlberg. 1998. Tariff rate quotas: Structural and stability impacts in growing markets. Agricultural Economics 19: 257-67. [CrossRef]

Bagwell, Kyle, and Robert W. Staiger. 2016. The design of trade agreements. In Handbook of Commercial Policy. Amsterdam: Elsevier.

Barichello, Richard. R. 2000. A Review of tariff rate quota administration in Canadian agriculture. Agricultural and Resource Economics Review 29: 103-14. [CrossRef]

Beckman, Jayson. 2021. Do Tariff-Rate Quotas Function as Intended by the World Trade Organization? Amber Waves: The Economics of Food, Farming, Natural Resources, and Rural America. [CrossRef]

Beckman, Jayson, John Dyck, and Kari Herman. 2017. The Global Landscape of Agricultural Trade, 1995-2014. In Economic Information Bulletin. Available online: https://www.ers.usda.gov/webdocs/publications/85626/eib-181.pdf?v=0 (accessed on 24 April 2021).

Bektasoglu, Beyhan, Kirsten Boysen-Urban, and Martina Brockmeier. 2011. Effects of Aggregation and Model Structure on Model Linkages. (No. 114721). Halle: German Association of Agricultural Economists (GEWISOLA).

Bendini, Roberto, June OKeefe, and Hannariika Nieminem. 2013. The 2013 Ministerial Conference in Bali: Last Chance for the WTO? Available online: https://www.europarl.europa.eu/RegData/etudes/briefing_note/join/2013/522310/EXPO-JOIN_SP(2013 )522310_EN.pdf (accessed on 23 March 2021).

Bertelsmann-Scott, Talitha, and Chelsea Markowitz. 2018. The Impact of the SADC EPA on South Africa's Agriculture and Agroprocessing Sectors. South African Institute of International Affairs, Policy Briefing 174. Available online: http://www.jstor.org/ stable/resrep28349 (accessed on 26 June 2021).

Bowen, Harry P., Abraham Hollander, and Jean-Marie Viaene. 2012. Applied International Trade. London: Macmillan International Higher Education.

Burfisher, Mary. 2011. Introduction to Computable General Equilibrium Models. Cambridge: Cambridge University Press.

CBI (Centre for Promotion of Imports from Developing Countries). 2015. CBI Trade Statistics: Processed Fruit and Vegetables in Europe. The Hague: CBI Market Intelligence, Ministry of Foreign Affairs.

Ciuriak, Dan, and Shenjie Chen. 2007. Preliminary Assessment of the Economic Impacts of a Canada-Korea Free Trade Agreement. Trade Policy Research, 187-234. Available online: http://www.sice.oas.org/TPD/CAN_KOR/Studies/economic_impacts_e.pdf (accessed on 12 May 2021).

de Gorter, Harry, and Ian Sheldon, eds. 2001. Agriculture in the WTO: Issues in Reforming Tariff-Rate Import Quotas in the Agreement on Agriculture in the WTO. St. Paul Minnesota: IATRC.

Decreux, Yvan, and Maria Priscila Ramos. 2007. How Does Tariff-Rate Quota Modelling Affect CGE Results? An Application for MIRAGE (No. 1423-2016-117716). Available online: https://ageconsearch.umn.edu/record/7206/ (accessed on 18 February 2021). 
Drogue, Sophie, and Maria Priscila Ramos. 2005. Tariff-Rate Quotas and Agricultural Trade: An Application to the Agricultural Free-Trade Negotiation between the MERCOSUR and the EU. Paper presented at 2005 International Congress, Copenhagen, Denmark, August 23-27; (No. 24637). Copenhagen: European Association of Agricultural Economists.

European Commission. 2020. TARIC and Quota Data and Information. Available online: https://circabc.europa.eu/ui/group/0e5f1 8c2-4b2f-42e9-aed4-dfe50ae1263b/library/90dd4b94-39dd-45f4-8f33-ec9ef9820016 (accessed on 5 December 2020).

Gervais, Jean-Philippe, and David Surprenant. 2000. An economic investigation of the import licensing methods and TRQs in agriculture. Canadian Journal of Agricultural Economics/Revue Canadienne D'agroeconomie 48: 397-410. [CrossRef]

Harberger, Arnold C. 1971. Three basic postulates for applied welfare economics: An interpretive essay. Journal of Economic literature 9: 785-97.

Hasha, Gene. 2004. European Trading Arrangements in Fruits and Vegetables; Washington, DC: US Department of Agriculture, Economic Research Service.

Herrmann, Ronald, Marc Kramb, and Christina Monnich. 2001. Tariff rate quotas and the economic impact of agricultural trade liberalization in the world trade organization. International Advances in Economic Research 7: 1-19. [CrossRef]

Hertel, Thomas W. 1997. Global Trade Analysis: Modeling and Applications. Cambridge: Cambridge University Press.

Huff, Karen M., and Thomas W. Hertel. 1996. Decomposition of Welfare Effects in the GTAP Model. GTAP Technical Paper, 5. Available online: https: / / www.gtap.agecon.purdue.edu/resources/download/2365.pdf (accessed on 18 February 2021).

IMF. 2020. World Economic Outlook: A Long and Difficult Ascent. Washington, DC: International Monetary Fund, October, Available online: https:/ / www.imf.org/external/datamapper/datasets/WEO (accessed on 18 February 2021).

Jatkar, Archana, and Chenai Mukumba. 2014. Unpacking the Bali Package: A Snapshot of the Bali Ministerial Decisions of the WTO Members. Available online: https:/ / www.cuts-citee.org/pdf/Unpacking_the_Bali_Package-A_Snapshot_of_the_Bali_ Ministerial_Decisions_of_the_WTO_Members.pdf (accessed on 25 April 2021).

Jensen, Hans Grinsted, and Ron Sandrey. 2013. A new approach to a regional Free Trade Agreement in East Africa: 'willing participants'. Stellenbosch: Tralac. Available online: https:/ /www.tralac.org (accessed on 24 April 2021).

Joerin, Robert. 2014. Improving market access: The role of auctions in converting tariff-rate quotas into single tariffs. Review of Agricultural and Applied Economics (RAAE) 17: 24-30. [CrossRef]

Khorana, Sangeeta. 2008. The Developmental Relevance of Tariff Rate Quotas as a Market Access Instrument: An Analysis of Swiss Agricultural Imports. Estey Journal of International Law and Trade Policy 9: 8-31.

Li, Xianghong, and Colin A. Carter. 2009. The Impacts of Tariff-Rate Import Quotas on Market Access. Research Paper. Davis: Department of Agricultural and Resource Economics, Kansas State University and University of California.

Lim, Song-Soo, and Ronald A. Babula. 2013. How Much Is It Worth to Protect Sensitive Products with Tariff-Rate Quotas?-A Korean Case. Journal of Rural Development 35: 83-108.

Lim, Song-Soo, and David Blandford. 2009. Korea's Tariff Rate Quota System: Impact of the Doha Development Agenda Proposals. Journal of Korea Trade 13: 1-19.

Loi, Alberico, Roberto Esposti, Mario Gentile, Mauro Bruni, Annachiara Saguatti, Serena Berisio, Luca Cuppari, Maurizio Aragrande, Therese Haller, and Martin Huber. 2016. Policy Evaluation of Tariff Rate Quotas. Report Mandated by the Swiss Federal Office of Agriculture. Bologna: Areté srl.

Meade, Birgit Gisela Saager, Jason H. Grant, and Anita Regmi. 2010. Trade and Welfare Impacts of Partial Liberalization of US Sugar TRQs: The Application of a PE/GE Modeling Approach. Paper presented at 2010 Annual Meeting, Denver, CO, USA, July 25-27; (No. 61657). City: Agricultural and Applied Economics Association.

Miranda, Pedro, O. Kume, and Guida Piani. 2010. Tariff quotas and the effects on the Brazilian agricultural exports to European Union. In La Reconnexion Agricole Nord-Sud. Quels Enjeux pour les Pays en Développement. Edited by Henri Regnault. Montpellier: CIHEAM, pp. 79-92. Available online: http://om.ciheam.org/om/pdf/a90/00801173.pdf (accessed on 12 April 2021).

Monnich, Christina. 2003. Tariff Rate Quotas: Does Administration Matter? (No. 16). Discussion Paper. No. 1610-2016-134561. Available online: https:/ / d-nb.info/1065392508/34 (accessed on 11 May 2021).

Nagurney, Anna, Deniz Besik, and June Dong. 2019. Tariffs and quotas in world trade: A unified variational inequality framework. European Journal of Operational Research 275: 347-60. [CrossRef]

NAMC. 2017. Trade Probe, Issue 69. May. Available online: https://www.namc.co.za/wp-content/uploads/2018/07/NAMC-DAFFTradeProbe-69-May-Issue.pdf (accessed on 24 April 2021).

Narayanan, Badri G., Thomas W. Hertel, and J. Mark Horridge. 2010. Disaggregated data and trade policy analysis: The value of linking partial and general equilibrium models. Economic Modelling 27: 755-66. [CrossRef]

Parliament of Republic of South Africa. 2013. Announcements, Tablings and Committee Reports No. 159-2013. Available online: http:/ / www.parliament.gov.za/live/commonrepository /Processed/20131118/555207_1.pdf (accessed on 24 February 2016).

Perez, Romain, and Mustapha Sadni Jallab. 2009. Preference erosion and market access liberalization: The African dilemma in multilateral negotiations on agriculture. Review of World Economics 145: 277-92. [CrossRef]

Plummer, Michael G., David Cheong, and Shintaro Hamanaka. 2011. Methodology for Impact Assessment of Free Trade Agreements. Mandaluyong City: Asian Development Bank.

Pouliot, Sebastien, and Bruno Larue. 2012. Import sensitive products and perverse tariff-rate quota liberalization. Canadian Journal of Economics/Revue Canadienne D'économique 45: 903-24. [CrossRef] 
Research and Markets. 2021. Preserving and Processing of Fruit and Vegetables in South Africa 2020. Available online: https: / / www.researchandmarkets.com/reports/5165360/ (accessed on 11 June 2021).

Skully, David W. 1999. The Economics of TRQ Administration. Available online: https://core.ac.uk/download/pdf/6457602.pdf (accessed on 25 June 2021).

Skully, David W. 2001. Liberalizing Tariff-Rate Quotas. In Agricultural Policy Reform in the WTO-The Road Ahead; Edited by Mary E. Burfisher. Washington: Market and Trade Economics Division, pp. 59-67. Available online: https://www.ers.usda.gov/ webdocs / publications/41330/31780_aer802_002.pdf? v=1639\#page=63 (accessed on 25 June 2021).

South Africa. Government Gazette. 2014. Department of Agriculture, Forestry and Fisheries: Procedures for Application, Administration and Allocation of Export Permits under the Trade, Development and Cooperation Agreement between the European Union and the Republic of South Africa for the year 2015. (Notice 1084). Government Gazette 593: 1-24.

South Africa. Government Gazette. 2015. Department of Agriculture, Forestry and Fisheries: Procedures for Application, Administration and Allocation of Export Permits under the Trade, Development and Cooperation Agreement between the European Union and the Republic of South Africa for the year 2016. (Notice 929). Government Gazette 604: 1-21.

South Africa. Government Gazette. 2018. Department of Agriculture, Forestry and Fisheries: Procedures for application, administration and allocation of export permits under the Trade, Development and Cooperation agreement between the European Union and the Republic of South Africa for the year 2019. (Notice 622). Government Gazette 640: 1-32.

TDCA (Trade, Development and Cooperation Agreement). 1999. Official Journal of the European Communities, L 311/3. Available online: https:/ / eur-lex.europa.eu/LexUriServ/LexUriServ.do?uri=OJ:L:1999:311:SOM:EN:HTML (accessed on 20 April 2021).

Tsigas, Marinos, and Jesse Mora. 2009. Effects of Foreign Import Tariffs and TRQs on US Food and Agricultural Exports. Available online: https:/ /iatrc.umn.edu/wp-content/uploads/seattle-Tsigas.pdf (accessed on 25 April 2021).

van der Mensbrugghe, Dominique, John C. Beghin, and Don Mitchell. 2003. Implementing Tariff Rate Quotas in Cge Models: An Application to Sugar Trade Policies in Oecd Countries. Paper presented at 2003 Annual Meeting, Montreal, QC, Canada, July 27-30; (No. 22098). Montreal: American Agricultural Economics Association.

van Lin, Micha, Aart van den Bos, and Nazeem Sterras. 2018. The Current State of Fruit \& Vegetable Agro-Processing in South Africa. Available online: https://agbiz.co.za/uploads / AgbizNews19/190215_Current-state-of-agro-processing-in\%20SA.pdf (accessed on 22 June 2021).

WCO. 2019. What Is the Harmonized System (HS)? Available online: http:/ /www.wcoomd.org/en/topics/nomenclature/overview / what-is-the-harmonized-system.aspx (accessed on 15 June 2021).

WTO. 2003. The WTO Agreement Series 3. Geneva: Agriculture.

WTO. 2013a. Briefing Note: Agriculture Negotiations-The Bid to 'Harvest' Some 'Low Hanging Fruit'. 9th WTO Ministerial Conference, Bali. Available online: https://www.wto.org/english/thewto_e/minist_e/mc9_e/brief_agneg_e.htm\#trq (accessed on 25 April 2021).

WTO. 2013b. Understanding on Tariff Rate Quota Administration Provision of Agricultural Products, as Defined in Article 2 of the Agreement on Agriculture. WT/MIN(13)/39. Geneva. Available online: https://www.wto.org/english/thewto_e/minist_e/ mc9_e/desci39_e.htm (accessed on 25 April 2021).

WTO Committee on Agriculture. 2000. Special Session-Market Access. Tech. Rep. G/AG/NG/W/37. Geneva: WTO.

WTO Committee on Agriculture. 2013. Tariff Quota Administration Methods and Fill Rates 2002-2011. Tech. Rep. TN/AG/S/26/Rev.1. Geneva: WTO.

WTO Committee on Agriculture. 2018. Tariff Quota Administration Methods and Fill Rates 2007-2016. Tech. Rep. G/AG/W/183. Geneva: WTO.

WTO Committee on Agriculture. 2019. Tariff Implementation Issues_Issues with Tariff Rate Quotas. Tech. Rep. JOB/AG/169. Geneva: WTO.

WTO Committee on Agriculture. 2020. Tariff Quota Administration Methods and Fill Rates 2014-2019. Tech. Rep. G/AG/W/183/Rev.1. Geneva: WTO.

WTO Market Access Group. 1993. Modalities for the Establishment of Specific Binding Commitments under the Reform Programme. Text. MTN.GNG/MA/W/24. Available online: https://www.wto.org/english/tratop_e/agric_e/1993_ur_modalities_w24_e. pdf (accessed on 25 April 2021). 